\title{
QUESTIONING NORTH KOREA'S DIGRAPHIC INFLECTION POINT: KIM IL SUNG'S 1964 AND 1966 CONVERSATIONS WITH LINGUISTS RECONSIDERED
}

\author{
WILLIAM STRNAD
}

\begin{abstract}
Kim Il Sung's 1964 and 1966 conversations with linguists are appropriately deemed important as the establishment of the North's "cultured language" as a standard, as well as guidance related to language purification and script. In the analysis of inflection point related to language planning and policy in the North, is the often guidance on re-enshrinement of teaching "Chinese characters" (hanja) in North Korean education. Clearly this was official pronouncement of functional, synchronic digraphia, which has been preserved and operationalized down to the present. Scholarship on these conversations, amounting to policy guidance, attribute the shift in policy related to script as an inflection point. The author of this article concurs with its importance, but with respect to digraphia in the North, the conversations related to hanja instruction served as a confirmation for what was a broad trend in North Korean language planning during the years 1953-1964, a language planning and policy fait accompli, diminishing the portrayal of the conversations as a digraphic inflection point in North Korea.
\end{abstract}

Key words: digraphia, North Korea, Kim Il Sung, language planning and policy (LPP)

\section{Introduction}

Of historical importance beyond the settlement of the structure or orientation of modern Korean digraphia in the North, which entailed hanja education despite "Korean script" (chosŏn'gŭl) exclusivity being established in North Korean print media, are the two "conversations" (kyosi) with linguists conducted by Kim Il Sung in 1964 and 1966. Ross King (1997; 2007) notes that these extended expositions on language praxis and politicized policy statements on language by Kim Il Sung radically rede- 
fined the ideological orientations and future directions of North Korean language policy, and was reflected in a remark by André Fabre who states that the 1964 and 1966 conversations with linguists were "a sort of act of birth of the new language in North Korea and the consummation of its linguistic divorce with the South" (Fabre 1998: 311, cited in King 2007: 212). King further observes that the two conversations are important for the insights they afford into general questions of language and national identity in North Korea. Indeed, the DPRK's two most prominent linguistics journals, the academic Chosŏn'ó'mun and the more populist Munhwaŏhaksŭp, both began to frequently feature articles from various points of view and interpretations in these conversations during the last half of the 1960s (King 2007: 212; 1997: 127-129).

Kumatani Akiyasu (1990) summarizes that the long-term result of these two "conversations with linguists" was to set the course of DPRK language policy along certain fixed lines: abolition of hanja from public life, and an emphasis on ingenuousness and purity in language, along with a sense that North Korea is somehow the last bastion of national purity in Korea. Concomitantly, with Kim Il Sung's highly personalized intervention in language policy in this way, Kumatani notes "the standardization of Kim Il Sung's idiolect" (Kumatani 1990: 105) became a distinctive feature of North Korean language policy. Such a personality cult had evolved in connection with the prominent North Korean leader (similar to that with Máo Zédōng in China) that Kim Il Sung's speech was seen as a standard to be revered and officially modeled; new words proposed by the leader were therefore automatically listed as elements of "cultured speech" in the evolving dictionaries and in the spread of the new standard. Additionally, any pronouncements on the meanings of newly coined words by Kim Il Sung were taken to be fully definitive. The "supremacy" of the leader was also "expressed in the printing of his name, which should be printed in Gothic letters and cannot be broken in the middle and carried over to the next line" (Ibid.: 106; on communist revolutionary tradition in North Korean language policy and Máo Zédōng, see M. S. Kim 1985: 122, 133).

\section{Kim Il Sung's 1964 and 1966 conversations with linguists}

Prior to the 1964 conversation, on 3 December 1963, Kim Il Sung had rendered personal guidance that the North's students must learn more hanmun, meaning hanja (K.H. Sim 1989: 197-199). In the 1964 conversation, Kim noted that the presence of hanja in South Korean newspapers and books suggested that North Korea, in order to be aware of developments in the South, should strengthen the teaching of hanja (M.S. Kim 1999: 94; 2005) for the purposes of ultimately achieving national of cultural unification between the North and South (JoongAng Ilbo, 14 August 2009). Kim Il Sung had concluded that with chosŏn'gŭl exclusivity being the new policy, 
there were nonetheless clear indications that hanja education was often neglected. In the same 1964 conversation, Kim expressed his will that hanja education would be reintroduced, lamenting that university graduates in North Korea had a difficult time with Korean language because of their lack of hanja knowledge (H.S Kim 1984: 128-129; Hatori 1991: 270; King 2007: 213-214).

Shim Jae Kee (1988) assesses the two primary subjects of the 1964 conversation were the problem of "script reform" (munja kaehyŏk) and the problem of "assuring

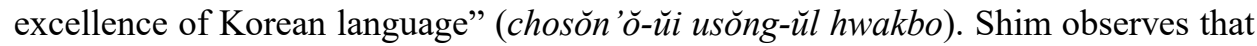
despite the issue of script having been a subject of lively discussion in North Korean academia after the Korean War, with the purging of Kim Tu-bong in 1958, discourse related to script had been largely unaddressed. This vacuum, according to Shim, further amplified the characteristics of the relative absence of dialogue regrading script reform, elevating the stated motivations for Kim Il Sung to express his opinion on the topic, which are paraphrased as follows: (1) the "script problem" (munja munje), being directly related to the "problem of unification" ( $t$ 'ong'il munje), that is division and unification, and has not been deeply addressed; therefore, the issue of script in South Korea as a consideration in the calculus of unification has not been considered; (2) the problem of script being a significant impediment to the "development of science and culture" (kwahak-gwa munhwa-ŭi paljŏn) has not been appreciated; and (3) in the twilight or fading of internationalism, there continues to be a gradual revival of nationalism, which has yet to be understood (J.K. Shim 1988: 4-5; M.S. Kim 1999: 94).

Kang Yŏng (1989) suggests five categorical areas or topics contained in Kim Il Sung's 1964 conversation: (1) reasons for "opposition to script reform doctrine" (munja gaehyŏngnon-ŭl pandae), which include first, the need to not have the scripts of a divided nation diverge, and the second, that script reform in the present context (1964) would interfere with the advancement of culture, science and technology, and third, that the Korean language will remain a "national" matter until the entire world is united under communism; (2) "hanja words must be managed" (hanjaŏ-rŭl chŏngnihaeya handa); (3) "foreign words must be managed" (woeraeǒ-rŭl chŏngnihaeya handa); (4) "write words with spacing" (tan'ǒ-rŭl ttŭiŏ ssŭnda); and (5) "the task of managing vocabulary must be undertaken" (ŏhwijŏngnisaŏp- $\breve{u l}$ haeya handa) (Y. Kang 1989: 16-18).

Sim Kyŏng-ho (1989), in his analysis of the impact of the 1964 conversation on the trajectory of North Korean LPP, states that Kim Il Sung's 1964 conversation contained the following essential points, either as necessity or guidance: (1) the construction of a single system for incorporating new hanja-words into the Korean language; (2) not to discard hanja-words that are well-established or frequently used in the Korean language; (3) to use Korean pronunciation, and not Chinese pronunciation of hanja-based lexicon; (4) there is no need to replace useful or common SinoKorean terminologies with fabricated pure-Korean alternatives; and (5) it is not 
necessary to use hanja in print media, and that hanja will be relegated to the education curriculum. Sim notes that the fifth and final point in the conversation signaled that North Korea's "basic position on the abolition of hanja" (hanja p'yeji-üi kibon ipjang) remained unchanged (K.H. Sim 1989: 197-198). William C. Hannas (1991) generally agrees with Sim Kyŏng-ho's characterization of the 1964 conversation, adding however, the importance of Kim Il Sung's mentioning the following: words should be spaced properly, including the arrangement or shape of words; local agencies need to be monitored and tightly controlled for correct use of words; the campaign to correct the use of language must be nationwide (Hannas 1991: 98).

For example, one such passage from the 1964 conversation "Some Problems Related to the Development of the Korean Language (3 January 1964)" (Chosŏn'ö-rŭl paljŏnsik'igi wihan myŏtgaji munje) (1964.1.3)) reads:

Now, as always, our spoken and written language serves as a powerful weapon in the development of the economy, culture, and science and technology of our country, in all fields of socialist construction. If we did not have a good spoken and written language, if we did not have our long history and cultural traditions which have been shaped and handed down through the medium of language, if our written language was not accepted by the entire people today and, accordingly, failed to help raise "the ideological consciousness and the technical and cultural level of the working people" (küllojadŭr-ŭi sasangsik-gwa kisulmunhwasujun) rapidly, then we would not be able to advance quickly in socialist construction in the saddle of Chŏllima (adapted from a North Korean English translation in I.S. Kim 1964, 1975: 388; 1964, 1968).

A reoccurring feature in North Korean political discourse, particularly since the invocation of the cultural revolution in the late $1950 \mathrm{~s}$, was the theme of morality, which increasing became injected into issue related to North Korean LPP, and is exemplified in the following passage from the 1964 conversation:

Our language is rich in expression and can express both complicated thoughts and subtle emotions: it can move people and bring them both to tears and laughter. Because our language is capable of expressing clearly the rules of etiquette, it is also useful in people's "communist moral upbringing" (kongsanjuŭidodŏkgyoyang) (I.S. Kim 1964, 1968, Munhwaŏhaksŭp, translated and cited in King 1997: 127)... The most important question that calls for our attention at present is that of the words borrowed from hanja, which have flooded our [Korean] language. Above all, we should have a correct attitude toward words adopted from hanja. Many words of Chinese origin that our ancestors used and then discarded are now being revived, and scores of new words are being coined by introducing hanja [words] at random. With "the development of science and technology and the progress of society" (kwahak-gwa kisur-i paljönhago sahoe-ga chŏnjin), our vocabulary must also be expanded. We must create a lot of new words. But we should make it a point to form these new words from our own root words (adapted from North Korean English translation in I.S. Kim 1964, 1975: 389). 
This passage recapitulates the sequentiality of Korean history: the narrative structure moving from hanja or hanmun, with the warning of the revival of impurity. This reflected the complexity of modern Korean digraphia and the remnants of nationalist discourse from the time of the late nineteenth century and through the Japanese Occupation Period. Kim Il Sung suggests that Chinese lexical items are nonKorean in origin and based on hanja, while at the same time, expresses a willingness to retain hanja-words that have no acceptable equivalent, or for that matter, a determination to reject pure Korean words that lack the necessary nuance of meaning, or are simply awkward. This is the convoluted byproduct of the axis of argumentation related to modern Korean digraphia beyond the use of Chinese characters in print media and/or in education versus Korean script exclusivity.

One important theme brought up (again) in the 1964 conversation is the issue of hanja, where we find the clearly articulated the notion (also characteristic of South Korea, and different from attitudes in Japan) that hanja are "not ours":

The question of using hanja must be considered together with that of our country's reunification. Nobody can prophesy exactly when our country will be reunified, but it is a foregone conclusion that the Yankees will go under, and our country be reunified someday. And since hanja are still being used by the people in South Korea, along with our own letters, we cannot abandon them entirely. If we discarded hanja completely now, we would not be able to read the newspapers and magazine printed in South Korea. We should, therefore, continue to learn and use hanja for the present. However, this does not mean, of course, that we should use hanja in our newspapers. All our publications should be written in our own letters (adapted from North Korean English translation in I.S. Kim 1964, 1975: 394; 1964, 1968: 1-7, cited in Hatori 1991: 270).

The 1964 conversation resulted in a proliferation of scholarly articles written on the topic of hanja and hanmun, such as: Pak Hong-jun, who published an article on 11 February 1964, Kim Tong-ho (1964), Pak Ǔi-sŏng (1964), Chŏn Che-su (1964), Ri Kŭn-yŏng (1964), Kim Kŭm-sŏk (1964), Han Ch’ŏl-jun (1965), and Chŏng Sungi (1965). Kim Tong-ho's article in the July 1964 edition of the Munhwaŏhaksŭp, entitled "Experiences Gained from Guidance on Vocabulary and Sentences" (Ǒhwi mit munjang chido-esŏ ŏdŭn kyŏnghŏm), calls for a reinvigoration of hanja education, observing that students have substantial difficulties in understanding and correctly using "hanja vocabulary" (hanjaŏhwi) (T.H. Kim 1964: 14, cited in M.S. Kim, 2005: 105).

Kim Min-su's survey of the articles in The People's Education Journal (Inmin'gyoyuk), demonstrates the concerted transformation in the official policy of North Korean education following the 1964 talk. For example, Han Ch'ŏl-jun's article "A Few Ways to the Enhancement of Hanmun Ability" (Hanmun sillyŏk chego-rŭl wihan myŏt kaji pangdo), in the December 1965 edition of the journal, enumerates examples of confusion among students in terms of lexical usage of Sino- 
Korean vocabulary concluding that strengthening hanmun (hanja) education is the answer (C.J. Han 1965: 29, cited in M.S. Kim 2005: 106). Ri Hyo-sŏp (1965), in an Inmin'gyoyuk article entitled "Points to be Noted in Hanmun Classes" (Hanmun poksŭp su'ŏp-eš̆ yuŭihal chŏm), recommends the following practices for students in hanmun (hanja) education:

(1) reading practice and content study (write many sentences with hanja on the board; read and reinforce the content through question and answer exchanges); (2) writing the learned hanja (writing chosŏn'gŭl words into hanja, ... including attention to the technique of writing; comparing similar hanja, etc.); (3) word construction; (4) writing a short composition; (5) writing antonyms; (6) finding hanja radicals; (7) comparing homonyms; (8) homework assignments (writing the new hanja at least twice, identifying the sound and meaning, writing hanja-based vocabulary words) (H.S. Ri 1965: 17, translated by author, cited in M.S. Kim 2005: 107).

Yi Yun-p'yo (1991) observes that articles published in The Journal of Korean Language Studies (Chosón'ǒhak), throughout the remainder of 1964 following the conversation with linguists in January, while reflecting a range of opinions, indicated a growing trend toward accommodating hanja words, especially for scientific and academic-technical use, with such linguists writing varied positions and approaches, such as Pak Hong-jun (February and November, 1964), Pak Chong-t'ae (February 1964), Pak Ǔi-sŏng (May and November, 1964), Chŏng Ryŏl-mo (May 1964), Chŏn Che-su (June 1964), Ri Kŭn-yŏng (July 1964), and Ri Man-gyu (September 1964). Pak Hong-jun in the February edition of the journal, recommends a balance in using "pure Korean language" (koyu chosŏnmal), to include "regional speech" (pang'ón) for ease of use, while retaining some hanja words and avoiding use of so-called "royal court hanja words" (kungjŏngjŏk'in hanjamal). In the same edition, Pak Chong-t'ae, asserts that the main task is finding pure Korean equivalents, the process must "ensure the ease of the stylistics" (munch'e-ǔi p'yong 'isong-ŭi pojang) of the Korean language. These two positions reflect North Korean linguist and hanja advocate Hong Ki-mun's long-standing approach to language purification. Pak Ǔi-sŏng in May reaffirms that "verbal language" (kuduó) has priority over a so-called "text-based language" (sǒsaŏ). Chŏng Ryŏl-mo, also in the May edition, questions the impact of radical language purification by raising potential problems in questionanswer scenarios. In the July edition, Chŏn Che-su and Ri Kŭn-yŏng, and both Pak Hong-jun and Pak Üi-sŏng in the November edition all argue for selective hanja words for retention and conversion to pure-Korean equivalents. The articles written by Ri Kŭn-yŏng and Pak Hong-jun offer a glimpse at the complexity of the issue at hand. Ri Kŭn-yŏng, for example, suggests that the reason for not purging hanjabased vocabulary from Korean is because scholars' knowledge of "pure Korean language" (koyu'ó) is still insufficient. Pak Hong-jun points out the need for a phased approach to converting words to pure Korean equivalents because of the 
inherent difficulty. Both Ri and Pak, however, stress that hanja-based vocabulary will eventually be purged, because hanja words have been part of a language "invasion" (ch'imt'u), or things having the "characteristics of invasion" (ch'imt'usŏng). Only Ri Man-gyu, writing in the September edition of the Chosón'ŏhak, remained strongly opposed to the retention of any Sino-Korean vocabulary (authors and works cited in Y.P. Yi 1991: 41-42). Ri Man-gyu, Pak Ǔi-sŏng and Kim Ryŏn-ch'ŏl, as former protegés of Kim Tu-bong, supported the call for script reform in the 1964 and 1966 conversations with linguists, though of the three, Ri was the most outspoken in his vigorous and unyielding opposition to the instruction of hanja and the retention of any hanja-words (S.I. Chang 1973: 34-35 and R. Ryu 1974: 25-27, both cited in M.S. Kim 1985: fn. 49, 137).

Yi Yun-p'yo (1991) comments that in a broad sense, the 1964 conversation with linguists was a culmination of the tract of language purification policy that was at the very heart of North Korean language policy. Particularly, during the period after the Korean War until the 1964 conversation, the central tension in North Korean LPP was the issue of language purification and therefore, the reconfiguration of hanja-words, terminologies that constituted the foundation of Korean academic language and specialized-technical or scientific language usage. This long-term evolutionary or developmental perspective is echoed in the analysis of Ko Yŏng-gŭn (1999). The 1964 conversation foreshadows the 1966 conversation's final politicization of North Korean LPP with the further assertion of Korean identity or Koreanness, in which the Korean language in the North would be "the true Korean language" (author's quotation marks for emphasis).

According to Ross King (1997; 2007), the 5 May 1966 conversation with linguists, "On Correctly Preserving the National Characteristics of the Korean Language" (Chosŏn'ŏ-ŭi minjokjŏk t'ǔksŏng-ŭl olke sallyŏnagallde taehayŏ) was concerned more with the question of "standard language" and the role of linguists in researching and establishing language norms. In this dialogue with assembled linguists, Kim Il Sung criticizes Seoul Korean, which had previously often been referred to as standard Korean, as being a poor model of speech for a developing socialist Korea, meaning North Korea. North Korean linguists have frequently vilified Seoul Korean as being the product of a feudal, bourgeois society and overcontaminated with foreign loanwords from Chinese, Japanese, and (more recently) English sources to the extent of becoming a mixed and impure language. The 1966 dialogue stresses the need to save the national character of Korean and develop it more. Kim calls for the recognition of a new standard Korean crafted by responsible, socialist experts and in tune with the language of the laboring masses. He reasons that such a more genuinely national and socialist language should be explicitly distinguished from Seoul Korean by being given a new name, thus the term "cultured language" (munhwaŏ) (King 1997: 127-128; K.S. Sŏ 1979: 113-126). Additionally, Kim Il Sung evidently desired to maintain cultural links with overseas Koreans and 
reasons that having a "cultured language" is needed as an advantage in the competition for recognition and legitimacy among Koreans in the diaspora (King 2007: 213). The new proposed term, an entry in the 1973 Korean Cultured Language Dictionary (Munhwaǒsajŏn), is as follows:

The richly developed national language that is formed centering around the revolutionary capital [P'yŏngyang] under the leadership of the proletarian party that holds sovereignty during the socialism-construction period, and that all people hold as a standard, because it has been reformed revolutionarily and polished culturally to fit the proletariat's goals and lifestyle (Munhwaŏsajŏn 1973, adaptation of an English translation, cited in H.M. Sohn 1991: 99).

Kang Yŏng (1989: 11-12) points out that for the majority of South Korean linguists focused on North Korean language policy and its history, Kim Il Sung's 1966 conversation with linguists represents the transition from the "divided orthography period" (chŏljebŏpgi) (1954-1966), based on morphological principles rather than phonetic/phonological principles to the "prescriptive period" (kyubǒpjipgi) (1966 to the present). The year 1966 also is referred to as the beginning of the "cultured language period" (munhwa-ŏ'gi), or alternatively, referred to as the "cultured language era" (munhwa-ǒsidae) (Tong'ilsinmun, 16 November 2018). These appellations, based on Kim Il Sung's proposed the term "cultured language" (munhwa-ð̌), suggest denotative guidelines based on principles of nativization and the P'yŏngyang dialect as the "standard pronunciation" (C.W. Kim 1978a: 166; Kumatani 1990: 87). Kim Hee-sook (1984: 132) specifies the importance of the 1966 conversation based on a different wording of the details such as the standardization of phonological elements, rules of word formation, more pure Korean terms, reinforcement of simplification in the decomposing and arranging chosŏn'gŭl predicated upon Chu Si-gyŏng's earlier scholarship, all of which resulted in the ultimate establishment of a 5,000 to 6,000 “common word" (bot'ong'ón'o) vocabulary.

Sim Kyŏng-ho (1989) and Kumatani Akiyasu (1990) both observe that the significance of the 1966 conversation with linguists is that North Korean LPP increasingly began to embrace politicized and nationalistic rhetoric, increasingly becoming associated with the "self-reliance ideology" (chuch'esasang). Additionally, Sim makes the three following points: (1) the 1966 conversation with its emphasis on creating new pure Korean terminologies marks the starting point of accelerating heterogenietization between the languages of North and South Korea; (2) the centering on the P'yŏngyang dialect as the standard is placed in the context of the contestation over legitimacy with South Korea, imply that the Korean language of the South was "a mongrel language ridden with foreign terms and hanja-words" (waeraeŏ-wa hanjaŏ-ga nanmuha'nŭn chapt'angmal); and that (3) the 1966 conversation was a continuation of two of the primary subjects of the 1964 conversation, specifically the problem of "script reform" (munja kaehyǒk) and the problem of 
"assuring the superiority of the Korean language" (chosŏn' $\breve{o r} \breve{i}$ usŏng-ŭl hwakbo) (M.S. Kim 1999: 94).

Kumatani states that because the 1966 conversation coincided with the advent of the active use of Kim Il Sung's ideas of chuch'esasang, North Korean language policy became enshrined as part of "North Korea's peculiar brand of socialist autonomy and self-reliance in all national matters, to include its "unitary ideology" (yuil sasang)" synonymous "with the idea of the uniqueness of the Korean race and culture", both of which became activated and highly important after 1967 (Kumatani 1990: 90). Kumatani adds that the "cultured language" while being largely based on P'yŏngyang speech, that is, the center of the revolution and of the North Korean government, is new speech but to a lesser degree, and more the idiolect of Kim Il Sung (Ibid.: 105-106), who increasingly embodied the struggle for liberation with a growing role of his guerrilla activities in the altering North Korean historical narrative, and seemingly congruent with his growing personal autocracy during the 1960s.

Shim Jae Kee (1988: 5), while asserting that the 1966 conversation is a continuation of the one held in 1964, underscores the 1966 dialogue as a significant demarcation, in that North Korean LPP assumed its characteristic politicized and highly nationalistic character after Kim Il Sung's 1966 conversation. Shim further characterizes the 1966 conversation as having signified the politicization of the written and spoken Korean language in the North, assessing that by the late-1960s, the "Vocabulary Refinement Movement" (maldadüm undong), carried an array of connotative political meanings in North Korea beyond "nativization of hanja words" (t'och'akhwahan hanja'mal); the two dialogues established chosŏn'gŭl "superiority" (ususong) in the North that had been reinforced since the late 1940s with the abolishment of hanja. In this process of continued nativization, a byproduct of operationalized and ideology-focused process, the North replaced many Japanese loanwords and Sino-Korean terms with newly coined native words. As a consequence decades after the 1964 and 1966 conversations, the North Korean government would ultimately solve the "homophone problem" that exists in Sino-Korean terms by deleting certain words with similar sounds from their lexicon (I.S. Lee and Ramsey 2000: 309-310).

Kim Il Sung's 1966 conversation with linguists exhibits parallels with Kim's speech to the Third Congress of the Korean Workers's Party on 23 April 1956, in that it too structurally recapitulates, in narrative form, portions of the Northern version of the historical struggle of the Korean language against "foreign language incursions" (author's use of quotation marks for emphasis), as follows:

During the feudal Yi dynasty "flunkeyism" (sadaejuŭi) towards China prevailed and a wide range of its vocabulary was imported. As a result, even now our people use a large vocabulary borrowed from hanja ... Following the seizure of our country by the 
Japanese imperialists in the past, our language was also adulterated extensively by Japanese words. That is why our present-day vocabulary contains a considerable number of Japanese-style words ... After liberation Russian words came to adulterate our language, which we checked (adapted from North Korean English translation in I.S. Kim 1966, 1975: 511-512).

Kim Il Sung chronologically narrates over five centuries of Korean history through the influences of foreign nations on the Korean language, suggesting that vestiges yet remain, and therefore the process of purification is essential for authenticity and preservation of Korean national identity. Continuing, Kim asserts that the South Korean language, both in print media and in speech, was "bastardized" with Sino-Korean, Japanese and English vocabulary:

We, the communists, must preserve the national characteristics of our language and develop them further. No Korean with a national conscience, even if not a communist, will be happy to see the national characteristics of our language die away. Except for the landlords, comprador capitalists, and reactionary bureaucrats, the masses of the people in South Korea, the overwhelming majority of the population, are patriotic-minded people who love our nation and our fatherland. So I believe they all hope for the development of our national language (adapted from North Korean English translation in I.S. Kim 1964, 1975: 513-514)... We should preserve and develop the "national language characteristics" (minjok'oüi t'üksŏng) with P'yŏngyang as the center and the speech of P'yŏngyang as the standard, because P'yŏngyang is the capital city and cradle of the revolution ...

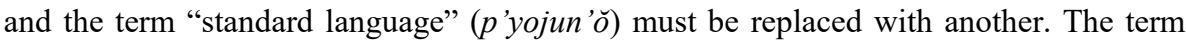
standard language may be incorrectly interpreted as meaning the Seoul dialect as the standard. Thus, there is no need to use it. It is proper that the language we who are the builders of socialism have developed based on the speech of P'yŏngyang, the revolutionary capital city, be given a name other than standard language ... the term "cultured language" (munhwaŏ) (adapted from North Korean English translation in I.S. Kim 1966, 1975: 518-519, and fused with portions of the translation in King 1997: 128).

Kim Il Sung in the last portion of the 1966 conversation renders guidance specific to Korean script and North Korean LPP, particular relative to translations and education, that would remain part of the central themes of the trajectory of North Korean LPP related to Korean digraphia:

"Ancient books" (kojŏn) must be translated by those who are well versed in hanmun. It will do well to open a Korean classics course of study at Kim Il Sung University and admit scores of clever students to teach hanmun, and [classical] literature, too. If four years of school studies is short, it may be extended to six years... While we restrict the use of words borrowed from hanja as far as possible, we must introduce to student necessary hanja and teach them how to read and write them. Quite a few of them appear in South Korean publications and old documents. If we are to enable people to read them, it is necessary for them to know a certain number of hanja... Even though we teach stu- 
dents hanja, none of these hanja should be allowed to appear in school textbooks in any form. If textbooks contain hanja, they will look like South Korean ones. If we cannot dispense with them just as the Japanese who need to use them together with their own scripts that will be another matter. But, if not so, there is no need to use hanja in school textbooks (adapted from North Korean English translation in I.S. Kim 1966, 1975: 524-525; 1966, 1969: 1-9, cited in M.S. Kim 1985; M.S. Kim 1999; Hatori 1991; and King 1997).

\section{Reconsidering the 1964 and 1966 conversations with linguists}

The 1964 and 1966 conversations with linguists, however, while altering the trajectory of North Korean LPP for generations, was not a substantive inflection point for present day North Korean digraphia; it was rather a symbolic underscoring of what had been in progress. Despite the official pronouncements of Korean script exclusivity, hanja had not disappeared from the North's LPP in the post-Korean War years during the 1950s. Hŏ Tong-ch'an points to the publication of hanja (hanmun) textbooks used for education in by Koreans in Japan during the 1950s and 1960s (T.C. Hŏ 1987; 1990, cited in Hatori 1991: 247). Hŏ confirms the continued publication of educational materials by North Korea in Japan, albeit for Korean residents in Japan. The materials in question contained much "mixed-script" (kukhanmun honyongch'e), for the following levels and years: elementary level middle school, first year (1955, 1956); advanced middle school, first year (1956, 1960); advanced middle school, second year (1956, 1960); advanced middle school, third year (1959, 1960). Yi Yun-p'yo (1989: 376) expresses skepticism of the notion that these textbooks being printed in Japan, and using elements of the Japanese language, would have been used in North Korea.

Although hanja had been abolished from print media and all official texts in 1949, North Korean linguist Chŏng Chi-dong (1956: 81-89) observes that hanja education was being conducted in the years following the signing of the armistice in 1953. Chŏng lists three applications, which were deviations from chosŏn'gŭl exclusively: (1) deciphering ancient texts; (2) understanding the origins and roots of SinoKorean words used in the national language; and (3) the advantage of studying Chinese culture. Chŏng, in this article entitled "Reform of the Korean Language Script" (Chosŏn'ŏ munja kaehyŏk), in the December 1956 edition (No. 6) of The Journal of Korean Language and Literature (Chosŏn ŏ'mun), writes that elementary and middle school students were supposed to be taught 600 characters, and high school students were to be taught an additional 1,200 characters, with an ultimate goal of 2,400 characters for university students (C.D. Chŏng 1956; also cited in M.S. Kim 1999: 104). Even after 1956, when the People's Republic of China adopted "simplified Chinese characters" (kanch'eja), North Korean schools continued to teach "traditional Chinese characters" (chŏngja), as it has done until to the present (Kuiwon 
2014). Ko Yŏng-gŭn (1999: 243), while not addressing the observations of Hŏ Tong-ch'an's deductions, opines that the analysis advanced by Hatori (1991) is sound, and suggests that it was not the polemics of pro-hanja North Korean scholars such as Pak Sang-jun that were the causal explanation for hanja being reinstated into curriculum of North Korean schools; Ko argues that the return of hanja appears to have been a spontaneous "resurrection" (puhwal) at each level of primary and secondary education after cessation of hostilities in 1953, perhaps as a matter of local communities simply implementing elements of education known to them from the period before the Korean War, amid the dislocation and destruction that was ubiquitous in the North after the war.

North Korea compiled and published its own Hanmun Textbook (Hanmun kyogwasŏ) in August 1959, which was designed to instruct students in grades five and six, that is "advanced middle school" (kogŭpjunghakkyo) (M.S. Kim 1985: 86; Hannas 1997: 67). Specifically, the textbook in question was formulated for introducing students to hanja-based (Sino-Korean) vocabulary in mixed script sentences. However, in October 1959, there was a sudden reorganization of the entirety of North Korean primary and middle school education system, which entailed the replacement of a two-year advanced middle school with a three-year "middle school" (chunghakkyo). As a consequence, the use of the textbook was suspended (K.H. Sim 1989: 197; M.S. Kim 1985: 86), although some 20,000 drafts of the textbook had been printed (T.I. Chu 2000: 472).

Politically, the 1949 official elimination of hanja in North expanded literacy among the population for indoctrination and modernization, while solidifying his political power base among the new political cadre. During the 1950s, noted linguist and Chairman of the Presidium of the Supreme People's Assembly since 1948, Kim Tu-bong, a member of the Yen'an faction, who being a scholar well-educated in "classical Chinese" (hanmun), was nonetheless an ardent champion of chosŏn'gŭl exclusivity as an assertion of nationalist identity based on the language nationalism of Chu Si-gyŏng, as part of what Yi Chun-sik (2008) refers to this group of North Korean scholars as the "Correct Sounds Faction" (Chŏng'ümp'a), reflecting the dominant term used in contemporary South Korean political discourse related to issue of script (P.G. Yi 2014: fn. 13, 18). The February and March 1958 purging of the Kim Tu-bong faction set the stage for the control and direction of language policy in North Korea. Historians refer to this as a movement from the "Era of Spelling" (Ch'óljabŏpsidae), a reference to Kim Tu-bong's emphasis on rules of standardized spelling for chosŏngŭl, to control of national language policy by Kim Il Sung, as early as 1960 (Y. Kang 1989: 14).

The purging of Kim Tu-bong opened a possible role of Hong Ki-mun and Hong Myŏng-hŭi in North Korea's LPP continuity toward official sanctioning of hanja education. Kim Il Sung had close connections with linguist Hong Ki-mun, and his father, Hong Myŏng-hŭi (1888-1968), who served as Deputy Prime Minister during 
the 1950s and 1960s. Hong Myŏng-hŭi's middle daughter, was the secretary to Kim Il Sung's wife, Kim Song-ae, during this period. Both the father and son were staunch proponents of retaining Sino-Korean vocabulary and structures. Hong Ki-mun was promoted to Full Professor at Kim Il Sung University in 1954 and was made the Director of the Institute of Science and Linguistics in 1957. The younger Hong's precipitous rise is made more intriguing by his father's erudition that encompassed writing hanmun, commentaries, scholarship and writing poetry. The father and son's close interactions with Kim Il Sung may have influenced Kim Il Sung's ultimate decision to publicly endorse hanja education during the conversations with linguists (U.S. Cho 2018).

Economics and security are likely were part of the calculus leading to the establishment of functional (limited) digraphia in the North. The first half of the 1960s, when Kim Il Sung first instructed hanja instruction, was when North Korea had turned its attention to potential trade expansion with Japan and China, in order to promote "joint-ventures" or "foreign-enterprise joint ventures". The acquisition of hanja was advantageous to the North, as P'yŏngyang would be in a better position to obtain much needed capital from Koreans in the diaspora in Japan, and from enterprises in Southeast Asian Chinese communities (P.J. Kim 2012).

P'yŏngyang's continued funding to the pro-North "General Association of Korean Residents in Japan" (J. Chōsen Sōren, K. Chosŏn Ch'ongnyŏn), especially for the creation of hanja study materials and textbooks was the desire to maintain cultural links were in no small measure related to the "Korean residents of Japan" (J. Zainichi), who were a source of financial support to North Korea amid the legitimacy struggle between the two Koreas, particularly through the pro-North organization (Shipper 2010: 59-60). In January 1958, the United States deployed its first nuclear weapons system with approximately 150 warheads, with more nuclear missile systems and nuclear bombs for fighters arriving in March of the same year (Kristensen and Norris 2017: 349-350). The security environment and its perceived growing threat was fueled by the withdrawal of Chinese forces in October 1958. Kim Il Sung perhaps reasoned that in addition to value of cultural links of ethnic Koreans in Japan, overseas Chinese populations, and a continued security relationship with China being considered by the North Koreans as a guarantor of North Korean security.

The two dominant discourses in North Korean language reform during the 1950s and the first half of the 1960s was "language purification" (ön'ösunjŏng), and the "management of hanja words" (hanjă chŏngni), with a third corollary discourse among North Korean scholars coming at the beginning after the second half of the 1950 s and into the 1960s regarding "academic language and specialized-technical language usage" (haksulyong'ŏ mit chŏnmun-kisul yong'ŏ) (Ibid.: 250). These issues had been central in the discussions of Korean linguists during the Japanese occupation period. The language environment of the North, however, was further made 
more complex by the "resurrection of hanja education" (hanjagyoyuk puhwal) in the years following the end of the Korean War (T.C. Hŏ 1987; 1990, cited in Hatori 1991). Ko Yŏng-gŭn (1999: 247-248) makes a similar observation of the relationship between "managing hanja words" (hanjaŏ chŏngni) and "academic usage, and specialized-technical usage" (haksulyong'ŏ mit chŏnmun'yong'ó-kisulyong'ŏ). Consequently, these two issues necessitated scholarly debate concerning hanja, a seeming contradiction given North Korea's abolition of hanja and declaration of chosŏn'gŭl exclusivity in 1949, but nonetheless deemed necessary because of the impact of attempts at purification of the Korean language. Scholars addressing this debate were as follows: Hong Ki-mun (1956, 1961, 1962), Ch'oe Hyŏn (1956), Pak Chunyŏng (1957), Ryu Ryŏl (1958, 1960, 1960), Chŏng Ryŏl-mo (1960), Chang Changmyŏng (1960, 1961), and Paek Ye (1962) (S.O. Lee 1992: 604; Y.P. Yi 1991: 38-40).

Hong Ki-mun, for example, wrote an article appearing in a 1956 (Vol. 1, No. 2) edition of The Journal of Korean Language and Literature (Chosŏn'ó'mun), entitled, "The Relationship between Pure Korean and Sino-Korean Vocabulary in the Structure of Basic Vocabulary and Lexicon of the Korean Language" (Chosŏn'ŏ-ŭi kibon'ǒhwi-wa ŏwi'gusŏng-esŏ koyuŏhwi-wa hanjaŏwi-ga kaji'nŭn kwangye), in which he suggests a foundation for managing hanja terminologies. Ch'oe Hyŏn, wrote seven articles in the same journal commencing with the 1956 (Vol. 1, No. 4) edition. Ch'oe advocates a methodology for converting Sino-Korean terms into pure Korean equivalents, observing that the then current Korean language publications in the North, though written exclusively in chosŏn'gŭl, are like before, when "suffixes using Korean letters were added to the end of hanmun" ( $t$ 'o), which indicated syntactical relationships. Ch'oe reasons that this analogy is proper because the Korean language is still using numerous Sino-Korean terminologies. Additionally, Ch'oe proposes the use of the term "realizing the purification of language" (ón'ojōnghwasil) in lieu of "national language purification" (kuk'ósunhwa); ón'ójŏnghwa became the most common term thereafter (works and authors cited in and S.O. Lee 1992: 604; Y.P. Yi 1991: 38-40; and S.H. Kang 1998). The Chosŏn'ŏ'mun, in its 1957, No. 4 edition renders comprehensive guidelines to the process of language purification in a series of terse admonishments or suggestions: "don't write in complex script"; "let's express ourselves in a Korean way [with Korean words]"; "let's carefully consider context"; "let's consider differences and the elements of similar sentences"; "let's think about doing establishing a good unified system of relationships between words and their meaning"; and "let's not use "redundant words" (kunmal)" (Y.P. Yi 1991: 401).

North Korean LPP during this period, in addition to negotiating the obvious difficulties of language purification, which entailed the struggle with terminologies and hanja-words, also addressed the need to negotiate nationalism and national identity. During the 1950s and 1960s, North Korean language specialists with knowledge of hanmun, and classical Chinese texts, began to translate these works into chosŏn'gŭl- 
only versions. The translation of these classics represents an attempt by the North Korean regime to appropriate history for political uses. The choices of the works reflect the political utilitarian applications relevant to the growth of ethnic nationalism in North Korea in the 1950s and 1960s, the background of which the logic of Korean digraphia played out. The first work translated, the Tong'gukbyong'gam (1450) immediately following the Korean War points to the reinterpretation of a "nationalist military past" (author's quotations for emphasis), no doubt done to bolster Korean identity following the Korean War. This work frames the DPRK as an inheritor of a long-martial tradition, having been victorious in the face of foreign invasions, in the distant past and recently, according to the regime's propaganda. The second work, the Yŏlhailgi, also published in 1955, is a testimony to the historical continuity of the relationship between China and North Korea as being "close as lips and teeth" (C. chúnchüxiāngȳ̄), an expression attributed to Máo Zédōng concerning the relationship between the two states in the years following the Korean War. Considering that some 200,000 Chinese People's Volunteers still remained in North Korea until October 1958, assisting with reconstruction and recovery, the translated work can be interpreted as the North's recognition of historical connectivity and political solidarity with China (details on China's post-Korean War presence in the North in Declassified U.S. State Department Special Files 1951-1956: 569-573, cited in Tian 2014: 3; K.H. Sim 1989: 198).

The issue of academic and specialized-technical language had been a focal point of controversy in North Korean LPP since the late 1940s, as language purification presented language challenges. The process of language purification, meaning the many instances of liquidation of Sino-Korean vocabulary, began to intensify in the late 1950s and early 1960s (for observations on script reform related to specializedtechnical language in North Korea, see C.T. Pak 1959). By 1961, a total of 45,600 lexical items from 26 areas had been revised, and during 1962, the work on the revision of 22,600 terms from eight areas commenced. Representative works during the early 1960s on the subject of academic and specialized-technical language, include the following: Ryu Ryŏl (1960, 1960), Sim Sang-rin, 1960, and Ri Man-gyu (1962). Ryu Ryŏl, May 1960, "A Few Principles Being Raised in the Revision of Academic Language" (Haksulyong'ǒsajŏng-esŏ chegidoenŭn myŏt kaji wŏnch'ik), who suggests a need to establish a foundation for the revision of academic language, in The Journal of Korean Language and Literature (Chosŏn'ó'mun), Vol. 3; Sim Sang-rin, 1960, "Academic Language of Yesterday and Today" (Haksulyong'̌̆-ŭi ŏje-wa o'nŭl), Words and Script (Mala-gwa kŭl), No. 10; and Ri Man-gyu, July 1962, "The Basic Principles of Academic Language Revision" (Haksulyong'ǒsajŏng-ŭi kibonwŏnch'ik), The Journal of Korean Language Studies (Chosŏn'ŏhak), Vol. 3 (authors and works cited in Y.G. Ko 1999: 250-252).

Signals of the official reemergence of functional digraphia, meaning hanja and Korean script, at least in education, were conspicuous by the late 1950s and early 
1960s. A notable indication was the publication of North Korea's New Chinese Character Dictionary (Saeokp'yön) in 1963, representing a change regarding the frames in which modern Korean digraphia existed in the post-Kim Tu-bong era. Research and compilation of the dictionary, according to the introduction, had begun a little over a year prior to publication, meaning 1961 or 1962. The prologue of the dictionary, written in conjunction with the fifteenth anniversary of the creation the Democratic People's Republic of Korea (DPRK), seems to be the unambiguous reversal of broad political rhetoric regarding tradition and script in the period 19451953. The logic of the 1949 North Korean "abolition of hanja" (hanja p'yeji) was that hanja was a symbol of the "ideology of serving the great" (sadaejuüi) and was a remnant of the class divisions in traditional Korea eloquent of the repression of the masses by the yangban elite. During the Japanese Occupation Period and after liberation, hanja was conflated with Japanese kanji and the Japanese attempts at assimilating Koreans while destroying Korean culture. The promulgation of chosŏn'gŭl exclusivity in print media was the Korean post-colonial exercise in reasserting national identity. In this text, however, the message has been moved from denigration of hanja as a symbol of cultural oppression to an example of the rich heritage of sagacious ancestors. Additionally, it is the political ideology of communism, embodied by the Korean Worker's Party, that now enables a brilliant light to illuminate this heritage.

Rather than denouncing the use of hanja as being elitist or of little value, as was numerous earlier criticisms, the compilers of The New Chinese Character Dictionary reference arguments that the study of hanja will serve to deepen the understanding of Sino-Korean lexicon, a long-standing functionality frame of those who supported hanja use and education since the first decade of the twentieth century. The compilers enumerate Korean works on hanja (hanmun) from the fifteenth through the nineteenth centuries, suggesting an almost Confucian sense and connectivity with these earlier academic writings as being a continuation of a "scientific" tradition in Korean scholarship, echoing some of the translated works of Silhak scholars during the seventeenth, eighteenth, and nineteenth centuries. Here the frames of identity and functionality have been transformed to accommodate instrumental policy decisions of the North Korean regime.

\section{Conclusion}

The North Korean revolution and its Marxist utopian development toward scientific and technical progress had opened the space for Kim Il Sung to officially sanction hanja education. The abolition of hanja had lost its post-feudal and postcolonial value as an act rectifying history, and the two writing systems, Korean script and Chinese characters, could serve to elevate a modern and socialist Korean 
language. Kim Il Sung's 1964 and 1966 conversations with linguists merits its role as a demarcation in the history of North Korean LPP. The conversations established a North Korea-centric language standard, accelerated purification and defined the principles for North Korean LPP for generations to come. However, the conversations occurred after the momentum toward a new form of functional digraphia had been fixed by both pragmatic considerations and ideological impulses reconfigured in the landscape of the still evolving Cold War.

\section{Bibliography}

Chang, S. I. 1973. “Ap'-ŭro uri kŭlja-nŭn ka-ro p'ur’ŏssŏya handa”. Munhwaŏhaksŭp 3. 34-35.

Cho, U.S. 2018. Ch'uakhan son-ŭi chinjja wŏnjo-nŭn pukhan Kim Il-sŏng. Mediapen, 22 February 2018. http://www.mediapen.com/news/view/334990 (accessed on 30 March 2020).

Chŏng, C.D. 1956. “Chosŏn'ŏ munja kaehyŏk (1)". Chosŏn ŏ'mun 6. 81-89.

Chosŏnrodongdangjŏngch'aeksa: Ŏn'óbumun. 1973. Sahoegwahakwŏn ch'ulp'ansa (ed.). P'yŏngyang: Sahoegwahakwŏn ch'ulp'ansa.

Chu, T.I. 2000. "Pukhan-ŭi hanmun kyoyuk pangbŏp". In: Han'gukhanmun gyoyuk hakhoe (ed.). Hanmungyoyuk'yŏn'gu 15. Seoul: Pak I-jŏngch'ulp'ansa. 471-499.

Fabre, A. 1994. "Re' forme et modernization de la langue core'enne". In: Fodor, I. and C. Hagège. (eds.). Language reform - History and future VI; La réform des langues - Histoire et Avenir VI; Sprachreform - Geschichte und Zukunft. Hamburg: Helmut Buske Verlag GmbH. 235-256.

Han, C.J. 1965. "Hanmun sillyŏk chego-rŭl wihan myŏt kaji pangdo". Inmingyoyuk 12. 29.

Hannas, W.C. 1991. "Korean views on writing reform”. In: Mair, V.H. (ed.). Sino-Platonic Papers 27. Schriftestschrift: Essays in Honor of John DeFrancis on His Eightieth Birthday. Philadelphia: University of Pennsylvania. 85-94.

Hatori, R. 1991. "Pukhan-ŭi hanja kyoyuksa". In: Kim, Min-su (ed.). Pukhan-ŭi Chosŏn'ŏ yŏn'gusa, 1945-1990 2. Seoul: Nokjin. 266-290.

Hŏ, T.C. 1987. "Ilbon-esŏ pon pukhan-ŭi hanja kyoyuk”. Pukhan 187. 102-109.

Hŏ, T.C. 1990. "Choch’ongnyŏn kyoyuk”. In: Kim, H.C. (ed.). Pukhan-ǔi kyoyuk. Seoul: Ŭlyu'munhoesa. 366-392.

Hong, Y.S. 1977. Nambukhan 'ŏn 'ŏgaenyŏm-ŭi ijilhwayŏn'gu. Seoul: Kukt'ot'ong'ilwŏn.

Kang, Y. 1989. “Ŏn'ŏhak-e kwanhan Kim Il-sŏng kyosi punsŏk - 1964nyŏn, 1966nyŏn kyosi-rŭl chungsim-ŭro”. In: Kim. M.S. (ed.). Pukhan-ǔi ǒhak hyŏngmyŏng. Seoul: Tosŏch'ulp'an paek'ǔi. $11-19$.

Kim, C.W. 1978. "Linguistics and language policies in North Korea". In: Korean Studies 2. Honolulu: Faculty Center for Korean Studies, University of Hawai'i. 158-175.

Kim, H.S. 1984. "Nambukhan ŏn'ŏhak mit ŏn’ójŏngch'aek-e kwanhan pigyo yŏn'gu”. Chejudaehakkyo nonmunjip 17. 127-153.

Kim, I.S. 1964/1968. "Chosŏn’ŏ-rŭl paljŏnsik'igi wihan myŏtgaji munje (1964.1.3)”. Munhwa'ŏ haksŭp 2. $1-7$.

Kim, I.S. 1964/1975. "Some problems related to the development of the Korean language: talk with the linguists”. In: On Juche in our revolution. P'yŏngyang: Foreign Languages Publishing House. 384-397.

Kim, I.S. 1966/1969. “Chosŏn’ŏ-ŭi minjokjŏk t'ŭksŏng-ŭl olke sallyŏnagallde taehayŏ (1966.5.14)”. Munhwa'ǒhaksŭp 3. 1-9. 
Kim, Il Sung 1966/1975. "On correctly preserving the national characteristics of the Korean language: talk with the linguists”. In: On Juche in our revolution. P'yŏngyang: Foreign Languages Publishing House. 511-528.

Kim, M.S. 1985. Pukhan-ŭi kuk'ŏyŏn'gu. Haksul yŏn'guch'ongsŏ 22. Seoul: Koryŏdaehakkyo ch'ulp'anbu.

Kim, M.S. 1999. "Pukhan-ŭi hanja kyoyuk". Saeguk'ŏ saenghwal 9.3. 93-124.

Kim, M.S. 2005. "Pukhan-ŭi hanja kyoyuk”. In: Hanja-nŭn kuk’ǒ-ǔi kibon'ida. 101-114. Seoul: Chŏnt'ongmunhwayŏn'guhoe.

Kim, P.J. 2012. Kim Il-sŏng kyosi "hanja, 3,000ja-rŭl karŭch'yŏra". Chogabje.com. http://www. chogabje.com/board/view.asp?C_IDX=48020\&C_CC= AZ (accessed on 1 December 2017).

Kim, T.H. 1964. “Ŏhwi mit munjang chido-esŏ ŏdŭn kyŏnghŏm”. Munhwaŏhaksŭp 7. 14.

King, R. 1997. "Language, politics, and ideology in the postwar Korea”. In: McCann, D. R. (ed.). Korea briefing: toward reunification. Armonk, NY and London: M.E. Sharpe. 107-144.

King, R. 2007. "North and South Koreas". In: Simpson, A. (ed.). Language and national identity in Asia. Oxford: Oxford University Press. 200-234.

Ko, Y.G. 1999. Pukhan-ŭi ŏn'ǒ'munhwa. Seoul: Sŏuldaehak'kyoch'ulp'anbu.

Kristensen, H. and R.S. Norris. 2017. "A history of US nuclear weapons in South Korea". Bulletin of the Atomic Scientists. 73.6. 349-357.

Kumatani, A. 1990. "Language policies of North Korea". International Journal of the Sociology of Language 82. 88-107.

Lee, I.S. and S.R. Ramsey 2000. The Korean language. Albany, NY: State University of New York Press.

Lee, S.O. 1992. "Pukhan-ŭi ŏhwiyŏn'gu/sajŏnp'yŏnch'an - Namhan-gwaŭi tongjilsŏng hoebok-ŭl wihan kich'o yŏn'gu - “. Ŏhak'yŏn'gu 28.3. 599-619.

Pak, C. T. 1959. "Kwahak kisul yong'ŏ-ŭi t’ŭksŏng-gwa kŭ-ŭi chosŏng subŏp-e kwanhayŏ”. Chosŏn ŏmun 1. 89-96.

Ri, H.S. 1965. "Hanmun poksŭp su'ŏp-esŏ yuŭihal chŏm”. Inmin'gyoyuk 1. 17.

Ryu, R. 1974. "Hyŏngmyŏng-ŭi widaehan Kim Il-sŏngdongji-ggesŏ naenoŭsin kŭljagae hyŏksasang". Munhwaŏhaksŭp 1. 25-27.

Saeokp'yŏn 1963. Chosŏn minjujuŭi inmin konghwaguk kwahakwŏn, kojŏn yŏn'guso p'yŏnch'an (comp.). P'yŏngyang: Kwahakwŏn ch'ulp'ansa.

Shim, J.K. 1988. “Munhwaŏ-wa maldadŭmgi”. Kuk'ǒsaenghwal 15. 2-20.

Shipper, A.W. 2010. "Nationalisms of and against Zainichi Koreans". Asian Politics and Policy. 1.2. $55-75$.

Sim, Kyŏng-ho 1989. "Pukhan-ŭi hanmun kyogwasŏ". Ko, Yong-gŭn (ed.). Pukhan insik 7. Mal-gwa gŭl. 197-221. Seoul: Ŭlyumunhwasa.

Sohn, H.M. 1991. "Language policies and language divergence in the two Koreas". In: Mair, V.H. (ed.). Sino-Platonic Papers 27. Schriftestschrift: Essays in Honor of John DeFrancis on His Eightieth Birthday. Philadelphia: University of Pennsylvania. 95-102.

Sŏ, K.S. 1979. Pukhan-ŭi 'munhwaŏ'-e kwanhan yŏn'gu. In: T'ong'ilmunjeyŏn'gu 8. 113-126. Taegu: Yŏngnamdaehakkyo.

Tian, W.X. 2014. Tóng shēng yì qì: Zhōngguó 1958nián cóng cháoxiăn quánbù chèjūn fāng’àn de xíngchéng. Cambridge, MA and Yenching: Harvard-Yenching Working Paper Series.

Yi, C.S. 2008. "Choe Hyŏn-bae-wa Kim Tu-bong - ŏn'ŭi pundan-ŭl mak'ŭn tu han'gŭlhankja”. Yǒksabip'yŏng 82.

Yi, P.G. 2014. "Mal[ŏn’ŏ]-ŭn nari-ŭi ponsŏng - Chu Si-gyŏng, Choe Hyŏn-bae, Yi Hŭi-sŭng-ŭl chungsim-ŭro". Saeguk'ǒsaenghwal 24.3. 3-19. 
Yi, Y.P. 1989. "Pukhan-ŭi hanja kyoyuk-e daehayŏ”. In: Kim, Min-su (ed.). Pukhan-ŭi ŏhak hyŏngmyŏng. Seoul: Tosŏch'ulp'an paek'ŭi. 365-377.

Yi, Yun. P. 1991. "Pukhan-ŭi kuk'ŏsunhwasa". In: Kim, Min-su (ed.) Pukhan-ŭi Chosŏn'ŏ yŏn'gusa, 1945-1990 1. Silyongbunya. Seoul: Nokjin. 33-56. 
